\title{
Some hematological parameters of Wistar rats treated with Chromolaena odorata leave extracts
}

\author{
Henshaw Uchechi Okoroiwu, ${ }^{1}$ Ifeyinwa Maryann Okafor, ${ }^{1}$ Emmanuel Kufre Uko, ${ }^{1}$ Item Justin Atangwho ${ }^{2}$ \\ ${ }^{1}$ Haematology Unit, Department of Medical Laboratory Science University of Calabar, Calabar; ${ }^{2}$ Department of \\ Biochemistry University of Calabar, Calabar, Nigeria
}

\begin{abstract}
This study was designed to investigate the effects of the different extracts of Chromolaena odorata leave on the hematopoietic system of Wistar rats. Solvent extraction was used for the ethanol and aqueous extractions while decoction method was used for the crude extraction. Fifty Wistar rats of both sexes weighing 140-180 g were used for this study. They were divided into ten groups each containing five rats. The animals were fed the extracts by oral gavage once daily for 21 days. Blood sample was collected
\end{abstract}

Correspondence: Henshaw Uchechi Okoroiwu, Haematology Unit, Department of Medical Laboratory Science, University of Calabar, Calabar, Nigeria.

Tel: +234-8038833901

Email: okoroiwuhenshaw@gmail.com

Key words: Chromolaena Odorata; Hematological parameters; Hematopoetic; Phytochemicals; Acute toxicity.

Contributions: OHU conceived the study; OHU, UEK and OIM are responsible for the experimental design; OHU, AJI and OIM participated in the leaf extraction process; OHU, OIM and UEK participated in the laboratory analysis of the haematological parameters; OHU performed the data analysis, and prepared the manuscript; UEK, OIM and AJI edited the manuscript. All authors read and approved the final manuscript.

Conflict of interest: the authors declare no potential conflict of interest.

Acknowledgements: authors are grateful to Prof. P. Ebong, the Coordinator of Endocrine Research Laboratory, Biochemistry Department University of Calabar for provision of working space and equipments and also Prof. A.A.A. Alaribe, the head of Department Medical Laboratory Science University of Calabar for approval to use equipment from the Postgraduate laboratory.

Received for publication: 29 July 2016.

Revision received: 20 March 2017.

Accepted for publication: 30 March 2017.

(C) Copyright H.U. Okoroiwu et al., 2017

Licensee PAGEPress, Italy

Journal of Biological Research 2017; 90:6210

doi:10.4081/jbr.2017.6210

This article is distributed under the terms of the Creative Commons Attribution Noncommercial License (by-nc 4.0) which permits any noncommercial use, distribution, and reproduction in any medium, provided the original author(s) and source are credited. via cardiac artery. Hematological parameters were analyzed using automation method. The ethanol extract gave the highest extract yield. The aqueous, ethanol and crude extraction had median lethal toxicity $\left(\mathrm{LD}_{50}\right)$ of $2738.6 \mathrm{mg} / \mathrm{kg}, 1581.1 \mathrm{mg} / \mathrm{kg}$ and 224.7 $\mathrm{mg} / \mathrm{kg}$, respectively. Significant difference $(\mathrm{P}<0.05)$ in the total white blood cell count was observed in the $75 \mathrm{mg} / \mathrm{kg}$ ethanol and $300 \mathrm{mg} / \mathrm{kg}$ crude extracts when compared with control group. Significant difference $(\mathrm{P}<0.05)$ in the hemoglobin concentration was observed in the $150 \mathrm{mg} / \mathrm{kg}$ ethanol extracts when compared with the control group. Significant difference $(\mathrm{P}<0.05)$ in the packed cell volume was seen in the $75 \mathrm{mg} / \mathrm{kg}$ aqueous, $150 \mathrm{mg} / \mathrm{kg}$ aqueous and $75 \mathrm{mg} / \mathrm{kg}$ ethanol extracts in respect to the control group. The mean cell volume, the mean platelet volume and platelet large cell ratio of the $75 \mathrm{mg} / \mathrm{kg}$ aqueous extract were significantly different $(\mathrm{P}<0.05)$ when compared with the control group. The present study showed possible treatment-induced hematopoietic function of $C$. odorata leave extracts.

\section{Introduction}

Therapeutic use of plants is as old as mankind. The connection between man and the search for drugs in nature dates from far past. ${ }^{1}$ Ever since ancient times people looked for drugs in nature. The beginning of medicinal plant use were instinctive as is the case with animals. ${ }^{2}$ Awareness to medicinal plant use is due to many years of struggles against illness in which man learned to pursue drugs in barks, seeds, fruits and other plant parts. ${ }^{1}$ Plant components used in therapeutics are termed phytochemicals and they represent naturally occurring chemical compounds present in plants that produce health benefits other than those attributed to micronutrients and macronutrients. ${ }^{3}$ Chromolaena odorata is a rapidly growing perennial herb with multi stemmed shrub and grows up to $2.5 \mathrm{~m}$ in open areas. ${ }^{4}$ Its common name is Siam weed. It has many local names depending on the tribe; Akwokko akpa (Ibibio), Bienqua (Ijaw), Obu inenawa (Igbo), Ewe Akintola (Ijebu). In Nigeria Chromolaena odorata is commonly called independent plant or Awolowo plant or Elizabeth plant.5-7 Chromolaena odorata leave decoction have been used in folk medicine for wound healing, stoppage of bleeding, and even in some communities where it was reported to be used in pile ailment. ${ }^{8}$ Moreso, it has acquired the reputation of medicinal herb for variety of ailments including malaria, dysentery, toothache, and fever. ${ }^{9}$ However, its hemostatic property have been reported in vivo and in vitro study. ${ }^{10}$ Despite immense literature on the hemostatic and antimicrobial activities of $C$. odorata, not much information is available on the effect of the leaf extracts on hematological parameters. 


\section{Materials and Methods}

\section{Preparation of plant parts}

Fresh leaves of $C$. odorota were harvested from farms along University of Calabar Staff Quarters road and were identified by Dr. J.K. Ebigwai of Botany Department, University of Calabar. The leaves were rinsed with distilled water and dried under shade. The dried leaves were ground into powder after which $200 \mathrm{~g}$ of the coarse powder was suspended in $1200 \mathrm{ml}$ of ethanol $(98.67 \%$ $\mathrm{BDH})$ and $1200 \mathrm{~mL}$ of distilled water for the ethanol and aqueous extractions, respectively and agitated thoroughly for about $10 \mathrm{~min}-$ utes with an electric blender. The suspensions were allowed overnight in a Westcool fridge $\left(4^{\circ} \mathrm{C}\right)$. Twenty four hours later, the mixtures were filtered with chess cloth and the filtrates concentrated in vacuo (rotary evaporator) to $10 \%$ of the original volume at $40^{\circ} \mathrm{C}$. These concentrates were kept in water bath at $37^{\circ} \mathrm{C}$ for complete dryness. These extracts were reconstituted in normal saline to an appropriate concentration before administration. ${ }^{11}$ Fresh leaves for the crude extraction were ground using manual grater followed by decoction and then gravimetric analysis. ${ }^{12}$

\section{Animal treatment}

A total of 50 apparently healthy Wistar rats of both sexes weighing 140-180 g obtained from the animal house, College of Medical Sciences University of Calabar were used for hematological evaluation while 39 mice weighing 60-80 g were used for the acute toxicity study. All the experimental animals were fed with standard animal feed and water ad libitum. All experiments were performed in accordance with the guidelines for care and use of laboratory animals of Faculty Animal Research Ethics Committee (FAREC-FBMS) Faculty of Basic Medical Sciences University of Calabar. ${ }^{13}$ Animal use protocols were approved by the Faculty Animal Research Ethics Committee (FAREC-FBMS) Faculty of Basic Medical Sciences University of Calabar with reference number 001B4216.

\section{Acute toxicity}

The acute toxicity study was performed using the method described by Lorke (1998). ${ }^{14}$

\section{Phytochemical analysis}

\section{Test for alkaloids}

Presence of alkaloid in the extracts was estimated by Mayer's, Wagner' and Dragendorrf's tests. Each of the extracts was stirred with $1 \%$ aqueous hydrochloric acid on water bath and filtered. Two milliliters of the filtrates (in each case) were added to Mayer's reagent, Wagner's reagent and Dragendorrf's reagent in separate tubes. Alkaloids react with each of the reagents to form precipitate. The turbidity of the precipitation with either of the reagents is proportional to the quantity of alkaloid present. ${ }^{15}$

\section{Test for tannins}

Ferric Chloride and Lead Acetate tests were used to detect the presence of tannins. The extracts were stirred with distilled water and filtered. Two milliliters of the filtrates were then added to $10 \%$ ferric chloride and $10 \%$ lead acetate in separate tubes. Tannin in the extract reacts with the ferric chloride and lead acetate to form a blue-black, green or blue-green precipitate (in each case). ${ }^{15}$

\section{Test for saponins}

Emulsifying and Frothing tests were used to detect the presence of Saponins. The extracts were warmed with distilled water and filtered. Three drops of olive oil was added to $2 \mathrm{ml}$ of the filtrate for the emulsifying test, while $4 \mathrm{ml}$ of distilled water was added to $1 \mathrm{ml}$ of the filtrate for the frothing test. Both were shaken. Presence of brown emulsion (for the emulsifying test) and frothing (for frothing test) confirmed presence of saponins. ${ }^{15}$

\section{Test for anthraquinone}

Presence of anthraquinone was detected by modified Borntrager's test. Ten milliliters of concentrated chloroform was used to dissolve the extracts. The resulting solution was then filtered. Two and half milliliters of the filtrate was then added to 2.5 $\mathrm{ml}$ ammonia solution and shaken vigorously. Presence of pink to red precipitates confirmed the presence of anthraquinones. ${ }^{15}$

\section{Test for glycosides}

Half a gram of the extracts was boiled with $5 \mathrm{ml}$ of dilute hydrochloric acid and the resulting solution was neutralized with sodium hydroxide solution and filtered. Two milliliters of the resultant filtrate was then added to Fehlings solution 1 and 2, mixed thoroughly and boiled in water bath for 2 minutes. The appearance of reddish-brown precipitates indicated a positive result. ${ }^{15}$

\section{Test for flavonoids}

The presence of flavonoid in the extracts was determined by sodium hydroxide method. The extracts were dissolved in distilled water and filtered. Two milliliters of the resultant filtrate was then added to two different tubes. Three drops of sodium hydroxide were added to the first tube and allowed to stand for 2 minutes. Three drops of sodium hydroxide and 3 drops of $0.5 \mathrm{~N}$ hydrochloric acid were added to $2 \mathrm{ml}$ of the filtrate in the second tube. Both mixtures were observed for precipitation and colour change. Production of yellow coloration in the first tube and transition from yellow to colourless in the second tube confirmed presence of flavonoids. ${ }^{15}$

\section{Study protocol}

The experimental animals were divided into ten groups and each group consisted of five animals. Group I served as control and received $0.2 \mathrm{ml}$ of normal saline vehicle. Group II animals received $75 \mathrm{mg} / \mathrm{kg}$ of aqueous extract. Group III received 150 $\mathrm{mg} / \mathrm{kg}$ of aqueous extract. Group IV received $300 \mathrm{mg} / \mathrm{kg}$ of aqueous extract. Group V received $75 \mathrm{mg} / \mathrm{kg}$ of the ethanol extract. Group VI received $150 \mathrm{mg} / \mathrm{kg}$ of the ethanol extract. Group VII received $300 \mathrm{mg} / \mathrm{kg}$ of the ethanol extract. Group VIII received the $75 \mathrm{mg} / \mathrm{kg}$ of the crude extract. Group IX received $150 \mathrm{mg} / \mathrm{kg}$ of the crude extract. Group X received the $300 \mathrm{mg} / \mathrm{kg}$ of the crude extract. Extracts for the test groups were dissolved in normal saline vehicle with respect to their concentration (extract dry weight per $\mathrm{kg}$ of the animal weight) and animal body weight. All dosages above were administered once per day via oral gavage for 21 days.

\section{Sample collection analysis}

At the end of the study, the animals were sacrificed and blood collected via cardiac artery into EDTA container and analyzed immediately using automated SYSMEX KX-2IN by Sysmex America Inc. (IL, USA) using Stromalyser reagent also produced by Sysmex America Inc. 


\section{Statistical analysis}

All values were expressed as Mean \pm SEM. Statistically difference between groups were determined using one way Analysis of variance (ANOVA) followed by Least significant difference test in significant cases using SPSS version 20 software. Differences were considered to be statistically significant when $\mathrm{P}<0.05$.

\section{Results}

The percentage yield of the ethanol and the aqueous extracts were $3.9 \%$ and $4.7 \%$ respectively while the crude extract gave yield of $0.046 \mathrm{mg} / \mathrm{ml}$ (Table 1). The crude extract contains Alkaloids, Tannins, Flavonoids, Saponins, Anthraquinones, Glycosides and Polyphenols. Alkaloids and Glycosides were absent in the aqueous extract while Anthraquinone was absent in the ethanol extract (Table 2$)$. The acute toxicity $\left(\mathrm{LD}_{50}\right)$ of the aqueous, ethanol and crude extracts were $2738.6 \mathrm{mg} / \mathrm{kg}, 1581.1 \mathrm{mg} / \mathrm{kg}$ and $1224.7 \mathrm{mg} / \mathrm{kg}$, respectively (Table 3).

The red cell count and the hemoglobin concentration of the $150 \mathrm{mg} / \mathrm{kg}$ of the aqueous extract were significantly $(\mathrm{P}<0.05)$ higher than the control. The packed cell volume of the $75 \mathrm{mg} / \mathrm{kg}$ and $150 \mathrm{mg} / \mathrm{kg}$ aqueous extracts were significantly $(\mathrm{P}<0.05)$ higher than that of the control group. The mean cell volume, the mean platelet volume and the platelet large cell ratio of the $75 \mathrm{mg} / \mathrm{kg}$ aqueous extract were significantly $(\mathrm{P}<0.05)$ greater than that of the control group (Table 4). The total white cell count, the red cell count, the hemoglobin concentration and packed cell volume of the $75 \mathrm{mg} / \mathrm{kg}$ ethanol extract were significantly $(\mathrm{P}<0.05)$ higher than the control group (Table 5). The total white cell count of the 300 $\mathrm{mg} / \mathrm{kg}$ crude extract was significantly $(\mathrm{P}<0.05)$ higher than the control group (Table 6).

\section{Discussion}

Hematological indices provide physiological information on the blood picture and the reticuloendothelial system. ${ }^{16}$ The present study observed higher yield in the aqueous extraction than the ethanol extraction. This observation is at variance with earlier report by Mbajiuka et al. (2014), ${ }^{17}$ who had higher value in the ethanol extraction. This study showed presence of bioactive phytochemicals such as Alkaloids, Tannins, Flavonoids, Saponins, Anthraquinones, Glycosides and Polyphenols in the crude extract with Alkaloids and Glycosides absent in the aqueous extract and Anthraquinones absent in the ethanol extract. This observation is

Table 1. Plant extract yield based on solvent used.

\begin{tabular}{lcc} 
Plant & Solvent & Yield \\
C. odorata & Ethanol & $3.90 \%$ \\
C. odorata & Aqueous & $4.76 \%$ \\
\hline C. odorata & Crude & $0.046 \mathrm{mg} / \mathrm{mL}$ \\
\hline
\end{tabular}

C. odorata, Chromolaena odorata.

Table 2. Phytochemical result of crude, ethanol and aqueous extracts of Chromolaena odorata leaves.

\begin{tabular}{lccc} 
Phytochemical & $\begin{array}{c}\text { Aqueous } \\
\text { extract }\end{array}$ & $\begin{array}{c}\text { Ethanolic } \\
\text { extract }\end{array}$ & $\begin{array}{c}\text { Crude } \\
\text { extract }\end{array}$ \\
Alkaloids & - & + & + \\
Tannins & + & + & ++ \\
\hline Flavonoids & + & ++ & +++ \\
Saponins & ++ & ++ & ++ \\
Anthraquinone & ++ & - & ++ \\
Glycosides & - & + & ++ \\
\hline Polyphenols & ++ & ++ & ++ \\
\hline,+++ present in appreciable quantity;,++ present; +, present in low quantity; -, not present.
\end{tabular}

Table 3. Results of acute toxicity study of the various leaf extracts of Chromolaena odorata.

\begin{tabular}{lc} 
Type of extract & $\mathrm{LD}_{50}(\mathrm{mg} / \mathrm{kg})$ \\
Aqueous & $2,738.6$ \\
Ethanolic & $1,581.1$ \\
\hline Crude & $1,224.7$ \\
\hline
\end{tabular}

Table 4. Some hematological parameters of aqueous leaf extract of Chromolaena odorata treated rats.

\begin{tabular}{lcccc} 
Parameter & Control & $75 \mathrm{mg} / \mathrm{kg}$ & $150 \mathrm{mg} / \mathrm{kg}$ & $300 \mathrm{mg} / \mathrm{kg}$ \\
WBC $\left(\times 10^{3} / \mu \mathrm{L}\right)$ & $9.5 \pm 0.6$ & $8.4 \pm 0.8$ & $7.0 \pm 0.5$ & $7.8 \pm 0.7$ \\
RBC $\left(\times 10^{6} / \mu \mathrm{L}\right)$ & $7.1 \pm 0.2$ & $6.8 \pm 0.1$ & $8.5 \pm 0.3^{*}$ & $1.1 \pm 0.2$ \\
\hline Hb (g/dL) & $12.5 \pm 0.4$ & $13.7 \pm 0.1$ & $15.6 \pm 0.6^{*}$ & $4.4 \pm 1.0$ \\
PCV $(\%)$ & $38.7 \pm 1.3$ & $44.7 \pm 0.2^{*}$ & $55.7 \pm 1.9$ & $40.2 \pm 1.2$ \\
\hline MCV (fL) & $54.4 \pm 0.9$ & $66.0 \pm 0.4^{*}$ & $18.3 \pm 0.8$ & $57.0 \pm 1.6$ \\
MCH (pg) & $17.7 \pm 0.9$ & $20.2 \pm 0.2$ & $32.2 \pm 0.6$ & $16.4 \pm 1.4$ \\
\hline MCHC (g/dL) & $32.5 \pm 1.2$ & $30.7 \pm 0.2$ & $510.5 \pm 82.2$ & $28.7 \pm 1.9$ \\
Platelet $\left(\times 10^{3} / \mu \mathrm{L}\right)$ & $682.2 \pm 89.6$ & $654.0 \pm 35.1$ & $7.8 \pm 0.4$ & $616.3 \pm 47.1$ \\
\hline MPV (fL) & $7.5 \pm 0.2$ & $8.6 \pm 0.1^{*}$ & $13.6 \pm 2.3$ & $7.7 \pm 0.1$ \\
P_LCR (\%) & $10.4 \pm 1.9$ & $16.8 \pm 0.8^{*}$ & & $12.2 \pm 1.5$ \\
\hline
\end{tabular}

Data expressed as mean \pm SEM; * significant difference from control $(\mathrm{P}<0.05)$. 
in the consonance with earlier report by Afolabi et al. (2007), ${ }^{7}$ and Inyang and Adegoke (2008), ${ }^{18}$ and in variance with report of Anyasor et al (2008). ${ }^{19}$ This variation is possibly due to differences in methodology. The result of this study showed that $C$. odorata did not negatively alter white cell indices rather, the $75 \mathrm{mg} / \mathrm{kg}$ ethanol, $300 \mathrm{mg} / \mathrm{kg}$ crude extract significantly increased the total white cell count in $C$. odorata treated rats. This rise in total white cell count may be due to hyper stimulation of hematopoietic regulatory elements which regulates proliferation by the extracts. ${ }^{20}$ Higher quantity of flavonoids in the ethanol and crude extract might be the reason for this observed leucocytosis as flavonoids have been reported to increase intracellular vitamin $\mathrm{C}$ synthesis and leucocytosis. ${ }^{21}$ This study showed significant increase in erythrocyte count in the $150 \mathrm{mg} / \mathrm{kg}$ aqueous and the $75 \mathrm{mg} / \mathrm{kg}$ ethanol extracts. This is confirmed by the increase in the haematocrit [packed cell volume (PCV)] and hemoglobin ( $\mathrm{Hb})$ since PCV and $\mathrm{Hb}$ are functions of total red blood cell as against expected anemia due to the presence of Saponin. The result of this study strongly suggests the possible role $C$. odorata leave extract may have in treatment - induced erythropoetic activity. Chromolaena odorata leaf extract could be incorporated into pharmaceutical products intended to boost erythropoietic activity. This suggestion is affirmed by earlier report of high iron content in the leave of $C$. odorata. $^{22}$ The Saponin paradox is explained by the fact that hemolytic saponins are toxic when given via intravenous route. ${ }^{23,24}$ This study observed increase in mean platelet volume in the 75 $\mathrm{mg} / \mathrm{kg}$ aqueous extracts showing improved platelet quality, hence its possible role in hemostatic as earlier reported. ${ }^{10}$ Increased mean platelet volume is an indication of larger and more reactive platelets resulting in increased platelet turnover. Larger platelets are more adhesive and tend to aggregate more than small platelets and contain more secretary granules. ${ }^{25}$

\section{Conclusions}

Both the aqueous and the ethanol leaf extracts of Chromolaena odorata significantly increased red cell count, hemoglobin concentration and packed cell volume in the experimental animal, suggesting its possible treatment induced hematopoietic activity

\section{References}

1. Biljana BP. Historical review of medical plant. Pharmacogn Rev 2012;6:1-5.

Table 5. Some hematological parameters of ethanolic leaf extract of Chromolaena odorata treated rats.

\begin{tabular}{lcccc} 
Parameter & Control & $75 \mathrm{mg} / \mathrm{kg}$ & $150 \mathrm{mg} / \mathrm{kg}$ & $300 \mathrm{mg} / \mathrm{kg}$ \\
WBC $\left(\times 10^{3} / \mu \mathrm{L}\right)$ & $9.5 \pm 0.6$ & $14.5 \pm 1.2^{*}$ & $10.9 \pm 0.7$ & $13.9 \pm 2.3$ \\
RBC $\left(\times 10^{6 / \mu \mathrm{L})}\right.$ & $7.1 \pm 0.2$ & $8.3 \pm 0.2^{*}$ & $6.5 \pm 0.1$ & $7.5 \pm 0.1$ \\
\hline $\mathrm{Hb}(\mathrm{g} / \mathrm{dL})$ & $12.5 \pm 0.4$ & $13.4 \pm 0.9^{*}$ & $12.7 \pm 0.2$ & $13.0 \pm 0.4$ \\
PCV (\%) & $38.7 \pm 1.3$ & $46.9 \pm 1.7 *$ & $38.3 \pm 1.2$ & $40.8 \pm 0.3$ \\
\hline MCV (fL) & $54.4 \pm 0.9$ & $56.6 \pm 1.3$ & $57.6 \pm 1.6$ & $54.4 \pm 1.1$ \\
MCH (pg) & 17.70 .9 & $16.3 \pm 1.4$ & $19.1 \pm 0.2$ & $17.3 \pm 0.8$ \\
\hline MCHC (g/dL) & $32.5 \pm 1.2$ & $28.9 \pm 2.7$ & $33.2 \pm 0.7$ & $31.8 \pm 0.9$ \\
Platelet $\left(\times 10^{3} / \mu \mathrm{L}\right)$ & $682.2 \pm 89.6$ & $879.4 \pm 117.1$ & $800.8 \pm 77.9$ & $656.0 \pm 30.8$ \\
\hline MPV (fL) & $7.5 \pm 0.2$ & $7.5 \pm 0.5$ & $7.1 \pm 0.2$ & $7.1 \pm 0.3$ \\
P_LCR (\%) & $10.4 \pm 1.9$ & $11.4 \pm 2.8$ & $8.3 \pm 1.0$ & $8.3 \pm 1.1$ \\
\hline
\end{tabular}

Data expressed as mean \pm SEM; *significant difference from control $(\mathrm{P}<0.05)$.

Table 6. Some hematological parameters of crude leaf extract of Chromolaena odorata treated rats.

\begin{tabular}{|c|c|c|c|c|}
\hline Parameter & Control & 75 mg/kg & 150 kg/mg & 300 mg/kg \\
\hline $\mathrm{WBC}\left(\times 10^{3} / \mu \mathrm{L}\right)$ & $9.5 \pm 0.6$ & $11.6 \pm 0.8$ & $10.8 \pm 1.7$ & $16.0 \pm 5.4^{*}$ \\
\hline $\mathrm{RBC}\left(\times 10^{6} / \mu \mathrm{L}\right)$ & $7.1 \pm 0.2$ & $7.2 \pm 0.2$ & $7.7 \pm 0.2$ & $6.9 \pm 0.9$ \\
\hline $\mathrm{Hb}(\mathrm{g} / \mathrm{dL})$ & $12.5 \pm 0.4$ & $12.9 \pm 0.8$ & $13.7 \pm 0.7$ & $12.7 \pm 2.4$ \\
\hline PCV (\%) & $38.7 \pm 1.3$ & $40.2 \pm 1.3$ & $42.1 \pm 1.0$ & $37.1 \pm 6.9$ \\
\hline MCV (fL) & $54.4 \pm 0.9$ & $55.7 \pm 0.2$ & $54.0 \pm 0.8$ & $53.5 \pm 2.7$ \\
\hline $\mathrm{MCH}(\mathrm{pg})$ & $17.7 \pm 0.9$ & $17.9 \pm 0.6$ & $17.6 \pm 1.0$ & $18.2 \pm 0.9$ \\
\hline $\mathrm{MCHC}(\mathrm{g} / \mathrm{dL})$ & $32.5 \pm 1.2$ & $32.1 \pm 1.1$ & $32.6 \pm 1.5$ & $34.1 \pm 0.1$ \\
\hline Platelet $\left(\times 10^{3} / \mu \mathrm{L}\right)$ & $682.2 \pm 89.6$ & $711.3 \pm 76.5$ & $781.0 \pm 84.1$ & $814.0 \pm 63.0$ \\
\hline MPV (fL) & $7.5 \pm 0.2$ & $7.1 \pm 1.2$ & $6.7 \pm 0.2$ & $7.3 \pm 0.5$ \\
\hline P_LCR (\%) & $10.4 \pm 1.9$ & $8.1 \pm 0.5$ & $6.6 \pm 0.7$ & $8.8 \pm 1.5$ \\
\hline
\end{tabular}

Data expressed as mean $\pm \mathrm{SEM}$; ${ }^{*}$ significant difference from control $(\mathrm{P}<0.05)$. 
2. Stojanoski N. Development of health culture in Veles and its origin from the past to the end of the $20^{\text {th }}$ century. Veles Soc Sci Art 1999;1999:13-34.

3. Hasler CM, Blumberg JB. Symposium on phytochemistry: biochemistry physiology. J Nutr 1999;129:756S-57S.

4. Hataichanok P, Xiaobo Z, Jason L, et al. Hemostatic and wound healing properties of Chromolaena odorata leaf extracts. Dermatology 2013;2013:168269.

5. Omotayo MA, Avungbeto O, Sokefun OO, Eleyowo OO. Antibacteria activity of Crossocephalum crepidiodes (fireweed) and Chromolaena odorata (siam weed) hot aqueous leaf extract. Int Journal Pharm Biol Sci 2015;5:114-22.

6. Nwachukwu FC, Odo CE, Ihegboro GO. Effects of repeated administration of Chronolaena odorata on selected liver function parameters of apparently healthy wister rats. Eur J Biol 2015;3:13-24.

7. Afolabi CA, Ibukun EO, Dan-Oluge JA. Phytochemical constituents and antioxidants properties of extract from the leaf of Chromolaena odorata. Sci Res Essay 2007;2:191-4.

8. Egunjobi JK. Some common weeds of Western Nigeria. Abuja: Ministry of Agriculture \& Natural Resources; 1969.

9. Olajide OA, Tawo OB, Soyannwo OO. Studies of the antiinflammatory, antipyretic and antispasmodic properties of Chromolaena odorata. Pharm Biol 2000;38;367-70.

10. Okoroiwu HU, Atangwho JI, Uko EK, Okafor IM. Haemostatic property of Chromolaena odorata leaf extracts: in vitro and in vivo evaluation in Wistar rats. J Biol Res 2016;89: 56-60.

11. Atangwho IJ, Ebony PE, Eteng MU, Eyong EU. Effects of Vernonia amygdalina Del. on liver function in alloxan induced hyperglycemic rats. Int J Pharmacol 2007;3:143-8.

12. Havey DI. Modern analytical chemistry. Boston: McGrawHill; 2000.

13. Faculty Animal Research Ethics Committee (FAREC-FBMS), University of Calabar. Guidelines on the care and use of animals for scientific research purpose. Calabar: University of Calabar; 2015.
14. Lorke D. A new approach to practical acute toxicity testing. Arch Toxicol 1983;54:275-87.

15. Trease EC, Evans WC. Pharmacognosy. 12 th ed. London: Bailliere and Tindall; 1983.

16. Eyong EU, Umoh IB, Ebong PE, et al. Haematological effects following ingestion of Nigerian crude oil and crude oil polluted shell fish by rats. Nigerian J Physiol Sci 2004;19:1-6.

17. Mbajiuka CS, Obeagu EI, Chude CN, Ihezie OE. Antimicrobial effect of Chromolaena odorata on some human pathogens. Int J Curr Microbiol Appl Sci 2014;3:1006-12.

18. Inyang CU, Adegoke AA. Antibacterial properties and preliminary Phytochemical screening of Chromolaena odorata (siam weed or sapysa weed). Nigerian J Microbiol 2008;22:1652-9.

19. Anyasor GN, Aina DA, Olushola M, Aniyikaye AF. Phytochemical constituents, proximate analysis, antimicrobials and wound healing properties of leaf extracts of Chromolaena odorata. Ann Biol Res 2011;2:441-51.

20. Yakubu MT, Afoloayan AJ. Effects of aqueous extracts of Bulbine natalensis Baker stem on hematological and serum lipid profile of male wistar rats. Indian J Exp Biol 2009; 47:283-8

21. Lee KW, Kim YJ, Lee HJ, Lee CY. Cocoa has phenolic phytochemicals and higher antioxidant capacity than tears and red wine. J Agr Food Chem 2003;51:7292-5.

22. Suriyavathana M, Parameswan G, Shiyan S. Biochemical and antimicrobial study of Boerhavin erecta and Chromolaena odorata (L.) King \& Robinson. Int J Pharm Sci Res 2012; 2:465-8.

23. Bondi A, Birk Y, Gestertner B. Forage saponnins. In: Butler GW, Baily RW, eds. Chemistry and Biochemistry of herbage. London: Academic Press; 1973. pp. 511-28.

24. Cheeke PR. Nutritional and physiological implication of saponnins: A review. Lan J Anim Sci 1971;51:621-32.

25. Slavka G, Perkmann T, Haslacher H, et al. Mean platelet volume may represent a predictive parameter for overall vascular mortality and Ischemic heart disease. Arterioscler Thromb Biol 2011;31:1215-8. 